\title{
AKTA WIZYTACYJNE W STRUKTURZE ZASOBÓW HISTORYCZNYCH ARCHIWÓW DIECEZJALNYCH W POLSCE
}

\section{Wprowadzenie}

Tak ujęte zagadnienie wymaga na początek wyjaśnienia określeń stanowiących jego elementy składowe, a mianowicie: 1 . historyczne archiwum diecezjalne, 2. struktura zasobu wspomnianego archiwum, 3. akta wizytacyjne. Jednak w tym przypadku przedmiotem gruntowniejszych rozważań nie będą wymienione, poszczególne składniki tak zarysowanego tematu, ale będzie nim odpowiedź na pytanie, jakie miejsce w strukturze zasobów historycznych archiwów diecezjalnych w Polsce winna zająć grupa akt wizytacyjnych kościołów i parafii; w każdym $\mathrm{z}$ osobna archiwum tego typu to miejsce winno być takie samo ze względu na tożsamość ustrojową poszczególnych diecezji.

Terminu ,historyczne archiwum diecezjalne” używamy na określenie wyspecjalizowanej instytucji (działającej obecnie niemal w każdej diecezji w Polsce) powołanej do zabezpieczenia, gromadzenia, opracowywania oraz trwałego przechowywania i udostępniania materiałów archiwalnych ${ }^{1}$. Tego typu archiwa powoływano do życia już w latach międzywojennych. Nazwa ,archiwum historyczne” zaczęła funkcjonować w prawie kościelnym dopiero po wejściu w życie nowego Kodeksu Prawa Kanonicznego (1983).

Zasób archiwum to rozbudowana wielopoziomowa całość. Szczegółowe jej poznanie warunkuje zbudowanie właściwej informacji o zasobie (ważne szczególnie w dobie budowania komputerowej informacji o zasobie archiwum). Sam zasób archiwum jest najwyższym poziomem opisu; niższe to: grupa zespołów powiązanych ustrojowo, archiwum historyczne (zamknięte), zespół archiwalny. Podstawą wprowadzenia właściwego porządku w strukturze zasobu jest oparcie go o właściwie wyodrębnione zespoły archiwalne. Zespół archiwalny ma także

* Maria Dębowska - dr hab. historii, profesor w Ośrodku Archiwów Bibliotek i Muzeów Kościelnych KUL.

${ }^{1}$ M. Dębowska, Archiwa Kościoła katolickiego w II Rzeczypospolitej, „Archiwa, Biblioteki i Muzea Kościelne" [dalej: ABMK], 92 (2009) s. 39. 
swoją strukturę (podzespół, seria, podseria, jednostka archiwalna). Każda jednostka winna w niej znaleźć swoje właściwe miejsce ${ }^{2}$. W odniesieniu do archiwów diecezjalnych nie wypracowano jeszcze metody opracowywania materiałów archiwalnych z okresu księgi wpisów. Największą trudność sprawia więc zbudowanie właściwej struktury zasobów z tego właśnie okresu, ze względu na to, że w okresie staropolskim każdy rządca diecezji (biskup, administrator) miał własną kancelarię (obok tej funkcjonowała kancelaria oficjała generalnego czyli konsystorz generalny). Akta wizytacyjne należały do produkcji kancelaryjnej biskupów, którzy polecili je przeprowadzić. Ta wielość kancelarii rządców diecezji nakazywałaby wyodrębnienie wielu zespołów akt, operacji bardzo trudnej do przeprowadzenia w praktyce (ale czy niemożliwej?). Inne okresy w dziejach poszczególnych diecezji takich wątpliwości nie nastręczają, gdyż istniała jedna centralna instytucja diecezjalna (w okresie rozbiorów - konsystorz generalny nowego typu, po 1917 roku, czyli wydaniu Kodeksu Prawa Kanonicznego - kuria diecezjalna), której akta po przejściu do archiwum historycznego stanowią jeden zespół - chociaż bardzo rozbudowany.

W odniesieniu do interesującej nas grupy akt, jaką są wizytacje kościołów i parafii, należałoby zwrócić szczególną uwagę na dwa zagadnienia: 1. miejsce akt wizytacyjnych w zasobach historycznych archiwów diecezjalnych w dotychczasowej praktyce (jak jest), 2. przyporządkowanie akt wizytacyjnych do właściwie wyodrębnionego zespołu archiwalnego (jak być powinno). Przedmiotem rozważań będzie w tym przypadku przede wszystkim okres księgi wpisów, gdyż jest to zagadnienie najbardziej kontrowersyjne ze względu na problemy związane z właściwym wyodrębnieniem zespołów archiwalnych i utworzeniem dla nich odpowiednich nazw.

\section{Akta wizytacyjne w strukturze zasobów omawianych archiwów w dotychczasowej praktyce}

Akta wizytacyjne, ze względu na swoją wyjątkowość, częste wykorzystywanie do wielopłaszczyznowych badań naukowych, niekiedy są w archiwach grupowane w osobne całości i tak przechowywane. Podobnie zresztą czyni się z aktami metrykalnymi ${ }^{3}$. Tak wyodrębnione wizytacje pochodzą przynajmniej z kilku zespołów archiwalnych, $\mathrm{w}$ tym $\mathrm{z}$ zespołów akt poszczególnych parafii, $\mathrm{z}$ których materiały archiwalne zostały już przejęte do historycznych archiwów diecezjalnych. Nie jest naganne jeśli grupowanie akt wizytacyjnych w odrębne całości oznacza jedynie przeznaczenie dla nich szczególnego miejsca na półkach archiwalnych. Jednak rozmieszczenie archiwaliów w magazynach powinno służyć wyłącznie „fizycznemu dobru archiwaliów, a nie odbijać strukturę zasobu”4. Właści-

\footnotetext{
${ }^{2}$ Por. B. Ryszewski, Problemy komputeryzacji archiwów, Toruń 1994, s. 20-26.

${ }^{3}$ Tak czyniono we wszystkich archiwach (państwowych i kościelnych) z dokumentami. Obecnie ta praktyka jest poddawana krytyce.

${ }^{4}$ W. Chorążyczewski, Glos w sprawie zespolowości dokumentów staropolskich, w: Komputeryzacja archiwów, t. 3: Problemy zespołowości w archiwistyce i praktyce archiwów, red. H. Robótka, Torun 1997, s. 44.
} 
we miejsce na półce archiwalnej jest tylko jednym z elementów troski o fizyczne „zdrowie” archiwaliów.

Stworzoną w ten sposób całość (grupę akt wizytacyjnych) nie powinno się jednak nazywać zespołem archiwalnym, gdyż takowy tworzą „,organicznie powiązane ze sobą zarchiwizowane materiały archiwalne, wytworzone i zgromadzone w wyniku działalności urzędu (instytucji) lub osoby fizycznej" "5. Nazwa zespołu winna odpowiadać nazwie jednostki, która jest twórcą akt. W związku z tym można tu postawić retoryczne pytanie: czy w Kościele katolickim istniała czy istnieje instytucja (urząd) pod nazwą ,akta wizytacyjne”? Akta wizytacyjne wydzielone w osobne całości mogą stanowić co najwyżej kolekcję w archiwum kolekcjonera, ale nie zespół archiwalny w placówce, która ma ambicje być naukową instytucją. Tam obowiązuje archiwistę przestrzeganie pewnych ustalonych zasad.

\section{Przyporządkowanie akt wizytacyjnych do określonego zespołu archiwalnego}

\section{Twórcy akt wizytacyjnych}

Wielką wartość, w odniesieniu do archiwaliów z okresu staropolskiego, mają ustalenia ks. Stanisława Librowskiego ${ }^{6}$.

Sobór trydencki przywrócił pierwotny, duszpasterski sens wizytacji oraz przypomniał dawne uprawnienia i obowiązki biskupów jako odpowiedzialnych za wizytacje diecezji, mających je wizytować osobiście lub, jeśli stoją temu na przeszkodzie ważne przyczyny, przez swoich delegatów. W myśl postanowień tego soboru, archidiakoni i dziekani mieli obowiązek wizytowania podległych im okręgów de consensu episcopi ${ }^{7}$.

Z uwagi na to, że na osobie biskupa, jako rządcy diecezji, spoczywał obowiązek przeprowadzania wizytacji, więc, bez względu na to kto je odbywał (sam biskup lub duchowny przez niego delegowany, archidiakon czy dziekan), akta wizytacyjne przypisuje się biskupowi. Każda wizytacja, dokonana za rządów określonego biskupa powiązana jest właśnie z nim. Uznaje się, że to w kancelariach (zadwornych) poszczególnych biskupów wytworzone zostały akta wizytacyjne, zarówno protokoły wizytacji, jak i dekrety reformacyjne, nawet jeśli większość ich powstała w kancelariach wizytatorów.

Zarówno wizytatorzy, delegowani specjalnie do tej czynności przez biskupa, jak i archidiakoni i dziekani mieli obowiązek przekazać wytworzone przez siebie akta wizytacyjne do kancelarii biskupiej w ściśle określonym czasie. Tak więc, wszystkie akta wizytacyjne winny znaleźć się wśród produkcji kancelarii bisku-

${ }^{5}$ Polski stownik archiwalny, red. W. Maciejewska, Warszawa 1974, s. 91.

${ }^{6} \mathrm{~S}$. Librowski, Wizytacje diecezji włocławskiej. Część 1. Wizytacje diecezji kujawskiej i pomorskiej. Tom 1. Opracowanie archiwalno-źródtoznawcze - zeszyt 1: Wstęp ogólny do wizytacji, ABMK, 8 (1964) s. 13-186.

${ }^{7}$ S. Litak, $W$ sprawie publikowania i rejestracji akt wizytacyjnych kościołów i parafii, ABMK, 14 (1967) s. 134. 
piej. Dotyczy to zarówno kościołów parafialnych, jak i katedralnych czy kolegiackich. Akta wizytacji przeprowadzonych przez dziekana na zlecenie biskupa były odsyłane do kancelarii biskupich. Te należą także do kancelarii biskupiej, w odróżnieniu od protokołów wizytacji parafii należących do określonego dekanatu, które właściwi dziekani mieli obowiązek przeprowadzać corocznie z racji swego urzędu. Te protokoły pozostawały w kancelariach dziekanów i należą do archiwum wytworzonego przez dziekana ${ }^{8}$. Stąd też winny należeć do zespołu archiwalnego obejmującego dokumentację kancelarii dziekańskiej.

Akta wizytacyjne, które znalazły się w kancelarii biskupiej miały wartość praktyczną. Nie leżały spokojnie i porastały kurzem, ale wykorzystywane były w zarządzaniu diecezją. Wypożyczano je $\mathrm{z}$ pewnością wyższym urzędnikom (na przykład archidiakonom, oficjałom), stąd wiele z nich zaginęło - jak twierdził ks. Librowski ${ }^{9}$. Z pewnością służyły też kolejnym wizytatorom, by mogli wyciągnąć konsekwencje w stosunku do opornych duchownych, którzy nie podporządkowywali się zarządzeniom zawartym w dekretach reformacyjnych. Wizytatorzy także często wzorowali się na aktach sporządzonych przez swoich poprzedników. $\mathrm{Z}$ tychże akt sporządzano również odpisy dokumentów, wykorzystywanych w procesach sądowych.

Z czasem - tracąc wartość praktyczną - akta wizytacyjne były przekazywane pod opiekę kapituły katedralnej, a to dlatego, że miała ona stałą siedzibę w przeciwieństwie do kurii biskupich, które - będąc kancelarią biskupa (cancellaria curiae episcopalis) wędrowały razem z $\operatorname{nim}^{10}$. Czasami kapituła uważała powierzone sobie akta za swoje własne, co oczywiście było błędem naprawianym zwykle po zorganizowaniu diecezjalnego archiwum historycznego. Prawdopodobnie bywało i tak, że biskupi traktowali akta wizytacyjne jako własne i nie trafiały one do dokumentacji jego kancelarii zadwornej lecz do jego zbiorów prywatnych i czasami przepadały.

Przypomnijmy więc: akta wizytacji odsyłane do kancelarii biskupich należą do kancelarii poszczególnych rządców danej diecezji. Stąd dokumentacja powizytacyjna po zarchwizowaniu nie może stanowić w diecezjalnych archiwach historycznych osobnego „,zespołu” akt lecz jedynie część zespołu archiwalnego serię w zespołach archiwalnych obejmujących produkcję (dokumentację) kurii poszczególnych biskupów.

\section{Kwestia wyodrębnienia zespołów archiwalnych i nazwa zespołu archiwalnego obejmującego produkcję kancelarii biskupich}

Powstaje zasadniczy problem: pod jaką nazwą (nazwami) winien funkcjonować zespół archiwalny (zespoły archiwalne) obejmujący produkcję kancelarii biskupich w okresie staropolskim, jeśli wyodrębnimy taki (takie) w strukturze zasobu historycznego archiwum diecezjalnego. Do tej pory unikano jednoznacznego

\footnotetext{
${ }^{8}$ Librowski, Wizytacje diecezji włocławskiej [...]Wstęp ogólny do wizytacji, s. 132-135.

${ }^{9}$ Tamże, s. 135.

${ }^{10}$ S.K. Olczak, Kancelarie kościelne w okresie staropolskim, ABMK, 64 (1995) s. 16-17.
} 
rozstrzygnięcia tej kwestii. Jedynie S. Librowski przedstawił propozycję umiejscowienia akt wizytacyjnych w strukturze zasobu Archiwum Diecezjalnego we Włocławku ${ }^{11}$ :

\begin{tabular}{|c|c|}
\hline $\begin{array}{c}\text { ARCHIWUM } \\
\text { (przechowujące) }\end{array}$ & $\begin{array}{c}\text { Archiwum Diecezjalne } \\
\text { we Włocławku }\end{array}$ \\
\hline $\begin{array}{c}\text { ZESPÓŁ } \\
\text { (Arch. wytworzone) }\end{array}$ & $\begin{array}{c}\text { Archiwum Biskupów } \\
\text { Kujawskich i Pomorskich }\end{array}$ \\
\hline DZIAŁ & Wizytacje kośc. i par. \\
\hline Poddział & $\begin{array}{c}\text { Wizyt. gen. archidiakonatu } \\
\text { włocławskiego z r. } 1699\end{array}$ \\
\hline JEDNOSTKA & ABKP - wiz. 10 \\
\hline $\begin{array}{c}\text { SYGNATURA } \\
\text { (jednostki) }\end{array}$ & \\
\hline
\end{tabular}

Jak wskazuje tabela, w grupie akt staropolskich Librowski wydzielił zespół archiwalny, który nazwał „Archiwum Biskupów Kujawskich i Pomorskich”. Wydaje się jednak, że wspomniany zespół archiwalny jest tworem sztucznym, złożonym z wielu zespołów archiwalnych obejmujących produkcję kancelarii wszystkich biskupów tej diecezji z okresu księgi wpisów. Przypomnieć tu należy, iż w okresie staropolskim kancelaria (kuria) była związana bezpośrednio z osobą konkretnego biskupa, a nie z urzędem rządcy diecezji ${ }^{12}$.

Jak się wydaje, korzystne byłoby w tym przypadku wprowadzenie - jako jednego z elementów w strukturze zasobu archiwów - zamkniętego archiwum historycznego ${ }^{13}$, które objęłoby kancelarie rządców danej diecezji z okresu staropolskiego. Tak więc, ujęcie S. Librowskiego można byłoby potraktować jako wydzielenie zamkniętego archiwum historycznego biskupów kujawskich i pomorskich, w którym dopiero należałoby wyodrębnić zespoły, którymi byłyby kancelarie (czyli kurie) kolejnych rządców diecezji, jako że w praktyce kancelaria każdego rządcy winna stanowić odrębny zespół archiwalny pod nazwą „Kuria Biskupa NN” (ale nie: „Kuria Biskupia”). Akta wizytacyjne stanowiłyby w takim zespole archiwalnym odrębną serię akt (obok innych serii: akta uposażenia biskupstwa, akta działalności biskupów).

Schemat pokazujący miejsce akt wizytacyjnych w strukturze zasobu historycznego archiwum diecezjalnego wyglądałby następująco:

${ }^{11}$ Librowski, Wizytacje diecezji włocławskiej [...] Wstęp ogólny do wizytacji, s. 168.

${ }^{12}$ „Cechą najbardziej charakterystyczną kancelarii in curia episcopalis było jej ścisłe związanie nie tyle z samym urzędem biskupim, ile z samą osobą biskupa. Stąd dla każdego biskupa była to cancellaria nostra, zaś dla duchowieństwa diecezjalnego cancellaria reverendissimi”, Olczak, Kancelarie kościelne w okresie staropolskim, s. 16.

${ }^{13} \mathrm{~B}$. Ryszewski zaproponował wprowadzenie archiwum historycznego (zamkniętego) jako jednego z elementów w strukturze zasobu archiwów na określenie zespołu lub grupy zespołów stanowiących wytwór działalności instytucji już nieistniejącej, zob. Ryszewski, Problemy komputeryzacji archiwów, s. 20. 


\begin{tabular}{|c|c|}
\hline $\begin{array}{l}\text { Nazwa historycznego archiwum } \\
\text { (archi)diecezjalnego - przechowującego }\end{array}$ & $\begin{array}{c}\text { Archiwum (Archi)Diecezjalne } \\
\text { w }\end{array}$ \\
\hline $\begin{array}{c}\text { Nazwa archiwum historycznego } \\
\text { - wytworzonego* }\end{array}$ & $\begin{array}{l}\text { Archiwum Biskupów } \\
\text { NN }\end{array}$ \\
\hline Zespół archiwalny & Kuria Biskupa NN \\
\hline Seria & Wizytacje kościolów i parafii \\
\hline Jednostka archiwalna & Wizytacja generalna NN \\
\hline
\end{tabular}

* Archiwum historycznego - wytworzonego, jako jednego z elementów struktury zasobu historycznego archiwum diecezjalnego (przechowującego).

\section{Podsumowanie}

Budowanie właściwej informacji archiwalnej to także cegiełka dokładana do poznania historii Kościoła katolickiego. Wiedza o poszczególnych instytucjach, urzędach: ich powstaniu, funkcjonowaniu, miejscu w szeregu innych instytucji jest potrzebna nie tylko archiwistom. Praca archiwisty nie jest tylko pracą technika, ale także badacza.

Żadne z powyższych stwierdzeń, nie ma na celu burzenia zastanego już fizycznego porządku w archiwach diecezjalnych, gdyż obecnie istniejące systemy informatyczne pozwalają na zbudowanie metodologicznie poprawnej struktury zasobu bez burzenia okrzepłych fizycznych układów. Trzeba sobie jasno powiedzieć, że każde archiwum diecezjalne ma już w jakiś sposób uporządkowany zasób, sygnatury funkcjonują już w obiegu naukowym. Fizyczne zburzenie tego układu prawdopodobnie nie w każdym przypadku byłoby celowe i pożądane. Archiwiści kościelni nie powinni jednak uciekać od postawienia sobie pytania, czy struktura zasobu ich archiwów zgodna jest z zasadami przyjętymi w archiwistyce. 


\title{
VISITATION RECORDS IN THE STRUCTURE OF THE FONDS OF HISTORICAL DIO- CESAN ARCHIVES IN POLAND
}

\begin{abstract}
Summary
The following paper suggests that the visitation records of churches and parishes from the Old Polish period be held in the structure of the fonds of diocesan historical archives (storing). This issue is omitted both in theory and practice of diocesan archives in Poland due to difficulties (or, as many claim-impossibility) in applying the principle of provenance to the production of the episcopal chancery during the period of functioning the book of inscriptions. So far, only the Rev. Stanisław Librowski has suggested the project to solve this problem. This project, however, does not fully respect, acknowledged in the archival science, the principle of provenance.
\end{abstract}

Translated by Aneta Kiper 